\title{
Infiltrative lung diseases: Complications of novel antineoplastic agents in patients with hematological malignancies
}

\author{
Bobbak Vahid $\mathrm{MD}^{1}$, Paul E Marik MD FCCP ${ }^{2}$
}

\begin{abstract}
B Vahid, PE Marik. Infiltrative lung diseases: Complications of novel antineoplastic agents in patients with hematological malignancies. Can Respir J 2008;15(4):211-216.

Infiltrative lung disease is a well-known complication of antineoplastic agents in patients with hematological malignancies. Novel agents are constantly being added to available treatments. The present review discusses different pulmonary syndromes, pathogenesis and management of these novel agents.
\end{abstract}

Key Words: Chemotherapy; Pneumonitis; Pulmonary toxicity; Respiratory failure

$\mathrm{P}$ ulmonary involvement is a common and challenging condition in patients with hematological malignancies. Infiltrative lung diseases as a result of antineoplastic agentassociated pulmonary toxicity are being increasingly recognized as a cause of lung disease in patients with hematological malignancies. New agents are constantly being added to the list of available antineoplastic agents. Old medications with new indications (eg, thalidomide for multiple myeloma) may also cause pulmonary disease. Although pulmonary toxicity due to the older antineoplastic agents (bleomycin, busulfan, cyclophosphamide, methotrexate, melphalan, cytarabine and carmustatin) is well known, significant pulmonary toxicity may occur with the newer antineoplastic agents. The present article reviews the infiltrative lung diseases induced by novel antineoplastic agents in patients with hematological malignancies. Bone marrow transplantation and related pulmonary toxicities are not included. Various terms and definitions have been used in the literature to describe pulmonary complications of antineoplastic agents. To have a more unified understanding, we divided the antineoplastic agent-associated infiltrative lung diseases into eight groups based on clinical and pathological manifestations: nonspecific interstitial pneumonitis/fibrosis; organizing pneumonia (OP); desquamative interstitial pneumonia (DIP); eosinophilic pneumonia; granulomatous pneumonitis; noncardiogenic pulmonary edema (NCPE) and acute respiratory distress syndrome (ARDS); diffuse alveolar hemorrhage (DAH); and retinoic acid syndrome (Tables 1 and 2). Although the differentiation among these groups is arbitrary and the conditions may overlap, these definitions provide a useful framework for the present review. It is also important to

\author{
Les maladies pulmonaires infiltrantes : Les \\ complications de nouveaux antinéoplasiques \\ chez des patients atteints de tumeurs \\ hématologiques malignes
}

La maladie pulmonaire infiltrante est une complication bien connue des antinéoplasiques chez les patients atteints de tumeurs hématologiques malignes. De nouveaux agents s'ajoutent constamment aux traitements disponibles. La présente analyse porte sur divers syndromes pulmonaires, différentes pathogenèses et diverses prises en charge de ces nouveaux agents.

emphasize that these patterns of lung injury for many antineoplastic agents have been described in limited case reports or small case series. On the other hand, patients with hematological malignancies often have multiple comorbidities and establishing a cause and effect relationship between specific agents and lung disease is sometimes a difficult task.

\section{ANTINEOPLASTIC AGENT-ASSOCIATED INFILTRATIVE LUNG DISEASES}

\section{Nonspecific interstitial pneumonitis/fibrosis}

Pneumonitis is an inflammatory condition of the lungs that is characterized by alveolitis and infiltration of the lung interstitium. The etiology of interstitial pneumonitis includes noninfectious (eg, idiopathic, medications, inhalational exposures, collagen-vascular disorders) and infectious (bacterial, viral or fungal pneumonia) causes. Antineoplastic agents are known to cause interstitial pneumonitis (Table 1). The clinical manifestations of antineoplastic-associated pneumonitis (ANAP) are nonspecific and include fever, dyspnea, chest pain, sputum production, hemoptysis, hypoxemia, leukocytosis and pulmonary infiltrates. Because pneumonia presents with a similar clinical picture, infectious causes should be excluded in patients in whom drug-induced pneumonitis is suspected. Patients with hematological malignancy are generally immunosuppressed and are therefore susceptible to opportunistic infections. Other conditions that mimic ANAP include cardiogenic pulmonary edema, aspiration pneumonitis, DAH, radiation pneumonitis and pulmonary infiltration of malignant cells (1). Patients with hematological malignancies receiving chemotherapy are exposed to variety of other medications with

${ }^{1}$ Dominican Hospital, Santa Cruz Pulmonary Medical Group, Santa Cruz, California; ${ }^{2}$ Thomas Jefferson University Hospital, Department of Pulmonary and Critical Care Medicine, Philadelphia, Pennsylvania, USA

Correspondence: Dr Bobbak Vahid, 700 Fredric Street, Suite 203, Santa Cruz, California 95062, USA. Telephone 831-425-1906,

fax 831-423-7579, e-mail bobbak_vahid@yahoo.com 
TABLE 1

Agents associated with antineoplastic agent-associated pneumonitis

\begin{tabular}{|c|c|c|c|c|}
\hline Agent & Class & Indications & Incidence & Clinical course \\
\hline Anagrelide & $\begin{array}{l}\text { Platelet-reducing } \\
\text { agent }\end{array}$ & $\begin{array}{l}\text { Essential thrombocytosis; } \\
\text { polycythemia vera }\end{array}$ & $0.70 \%$ & $\begin{array}{l}\text { Pulmonary fibrosis after one year. Respiratory failure is rare, steroid } \\
\text { therapy is effective }\end{array}$ \\
\hline Anthracyclines & Cytotoxic antibiotics & $\begin{array}{l}\text { Leukemia; lymphoma; } \\
\text { multiple myeloma }\end{array}$ & Rare & $\begin{array}{l}\text { Usually reported with concurrent use of other antineoplastic agents } \\
\text { (bleomycin, vincristine, cyclophosphamide, chlorambucil). } \\
\text { Steroid responsive }\end{array}$ \\
\hline Azacytidine & Demethylating agent & Myelodysplastic syndrome & $<5 \%$ & Respiratory failure is rare. \\
\hline Bortezomib & Proteasome inhibitor & Multiple myeloma & $15.2 \%$ & $\begin{array}{l}\text { Pneumonitis usually occurs four to } 12 \text { days after the first cycle, High } \\
\text { incidence has been reported in Japanese patients. Previous auto-stem } \\
\text { cell transplant may be a risk factor. Steroids may reduce the risk } \\
\text { of pneumonitis }\end{array}$ \\
\hline Cladribine & Purine analogue & Hairy cell leukemia & Rare & $\begin{array}{l}\text { Pneumonitis has been reported seven to } 10 \text { days after therapy. } \\
\text { Steroid responsive }\end{array}$ \\
\hline Dasatinib & $\begin{array}{l}\text { Tyrosine kinase } \\
\text { inhibitor }\end{array}$ & $\begin{array}{l}\text { Chronic myelogenous } \\
\text { leukemia }\end{array}$ & Rare & Steroid responsive \\
\hline Fludarabine & Purine analogue & $\begin{array}{l}\text { Non-Hodgkin's lymphoma; } \\
\text { chronic lymphocytic leukemia }\end{array}$ & $\begin{array}{c}1.8 \% \text { to } \\
8.6 \%\end{array}$ & $\begin{array}{l}\text { Pneumonitis occurs days to weeks after therapy. Pneumonitis may occur } \\
\text { after the first or subsequent therapies. Steroids are effective }\end{array}$ \\
\hline Imatinib & $\begin{array}{l}\text { Tyrosine kinase } \\
\text { inhibitor }\end{array}$ & $\begin{array}{l}\text { Chronic myelogenous } \\
\text { leukemia }\end{array}$ & $\begin{array}{c}0.2 \% \text { to } \\
1.3 \%\end{array}$ & $\begin{array}{l}\text { Pneumonitis develops after first week of therapy and up to } 9.5 \text { months } \\
\text { after treatment with imatinib }\end{array}$ \\
\hline Interferon-alpha & Interferon & $\begin{array}{l}\text { Chronic myelogenous leukemia; } \\
\text { hairy cell leukemia; non- } \\
\text { Hodgkin's lymphoma }\end{array}$ & $1.5 \%$ & Subacute to chronic pneumonitis \\
\hline Lenalidomide & $\begin{array}{l}\text { Thalidomide } \\
\text { derivative }\end{array}$ & $\begin{array}{l}\text { Multiple myeloma; } \\
\text { myelodysplastic syndrome }\end{array}$ & $6 \%$ & Hypersensitivity-like pneumonitis with lymphocytic alveolitis \\
\hline Procarbazine & Alkylating agent & Hodgkin's lymphoma & Rare & $\begin{array}{l}\text { Procarbazine-induced pneumonitis is usually seen in association with } \\
\text { MOPP (mechlorethamine, vincristine, procarbazine, and prednisone) } \\
\text { Pneumonitis usually occurs during or after (five to seven days) the } \\
\text { second or third cycle of procarbazine. Steroids are effective }\end{array}$ \\
\hline Rituximab & $\begin{array}{l}\text { Monoclonal } \\
\text { antibody }\end{array}$ & B-cell malignancies & Rare & $\begin{array}{l}\text { Pulmonary fibrosis is rare. Pneumonitis is usually seen in association } \\
\text { with CHOP (cyclophosphamide, doxorubicin, vincristine, and prednisone) }\end{array}$ \\
\hline Thalidomide & Thalidomide & Multiple myeloma & Rare & Pulmonary fibrosis is rare \\
\hline Tositumomab & $\begin{array}{l}\text { Monoclonal } \\
\text { antibody plus } \\
\text { iodine-131 }\end{array}$ & B-cell malignancies & Rare & $\begin{array}{l}\text { Interstitial pneumonitis and severe hemorrhagic pneumonitis } \\
\text { resulting in respiratory failure has been reported in patients }\end{array}$ \\
\hline Trofosfamide & Alkylating agent & Lymphoma & Rare & $\begin{array}{l}\text { Trofosfamide is metabolized to ifosfamide and to a lesser degree } \\
\text { cyclophosphamide, which are known to have pulmonary toxic effects }\end{array}$ \\
\hline
\end{tabular}

potential pulmonary toxicity (eg, granulocyte-colony stimulating factor, amphotericin B and acyclovir) (2-5). Pulmonary disease due to these medications should be considered in the differential diagnosis. Because clinical, imaging and laboratory findings of ANAP are nonspecific and any of the above-mentioned conditions can mimic ANAP, ANAP is a diagnosis by exclusion (1).

The incidence of ANAP varies considerably and has been reported in $0.1 \%$ to $15 \%$ of treated patients in various phase II or phase III trials (Table 1) (6-57). Concurrent use of steroids does not necessarily prevent the development of ANAP, and severe cases of ANAP have been described with thalidomide, lenalidomide, rituximab, bortezomib and anthracyclines. Clinical symptoms range from mild dry cough and dyspnea on exertion to rapidly progressive disease and respiratory failure. Fever is a common finding. Skin rash and wheezing are less common, and when present, suggest a hypersensitivity reaction. Nonspecific systemic markers of inflammation including leukocytosis with neutrophilia, elevated erythrocyte sedimentation rate, and elevated C-reactive protein are common. Peripheral eosinophilia and abnormal liver transaminases are uncommon and suggest a hypersensitivity reaction (6-57). Common computed tomography scan patterns are diffuse or patchy ground-glass opacities, diffuse reticular and reticulonodular pattern, focal or patchy consolidation, and multiple pulmonary nodules. Bronchoscopy is helpful in evaluation of patients with suspected ANAP. Bronchoalveolar lavage (BAL) and protected microbiology brush can be used to evaluate for infections. BAL cytology may also show viral cytopathic effects. Hypercellular BAL with neutrophilia or lymphocytosis is a common finding. Lung biopsy either by transbronchial technique or videoassisted thoracic surgery can be extremely helpful to demonstrate the presence of pneumonitis and exclude alternative diagnoses. Pathology findings include nonspecific pneumonitis, acute or chronic inflammatory interstitial infiltrates, fibrosis, vasculitis and scattered organizing pneumonia (6-57). ANAP is diagnosed when clinical and radiographic manifestations are compatible with ANAP and other potential causes are excluded. 
The mainstay of management of ANAP is the cessation of the culprit agent. Corticosteroid treatment is guided by anecdotal data. Methylprednisolone $1 \mathrm{~g} /$ day for three days in patients with respiratory failure has been used. Lower doses of corticosteroids (methylprednisolone $60 \mathrm{mg}$ every $6 \mathrm{~h}$ ) may be considered in less severe cases of pneumonitis. Corticosteroid taper based on clinical response and improvement in oxygenation is a reasonable strategy (58). Other measures, including empirical treatment for infections until the culture results are available and maintaining euvolemic status, are also important in ANAP management.

\section{OP}

$\mathrm{OP}$ is a pathological diagnosis characterized by polypoid intraluminal plugs of proliferating fibroblasts and myofibroblasts within alveolar ducts and interstitial infiltrates. OP is a wellknown type of drug-induced lung disease. OP presents clinically with fever, cough, dyspnea and pulmonary infiltrates on chest imaging. Exclusion of infection and lung biopsy are necessary for definitive diagnosis. Anthracyclines, cladribine, interferonalpha, rituximab and thalidomide have been associated with OP. Cessation of culprit agent and systemic corticosteroids should result in rapid resolution of respiratory disease $(21,59-66)$.

\section{DIP}

DIP is a less common form of lung pathology. DIP is mostly seen in smokers with idiopathic interstitial pneumonitis. DIP is characterized by uniform filling of distal airspaces by numerous pigmented alveolar macrophages. Multinucleated cells, eosinophils and lymphocytes are also present. The macrophages have abundant cytoplasm with finely granular dusty brown pigment. DIP-like pathology has been described with cladribine, interferon-alpha and rituximab. Lung biopsy is necessary for diagnosis. Cessation of culprit agent and systemic corticosteroids are mainstays of therapy $(21,67)$.

\section{Eosinophilic pneumonia}

Eosinophilic pneumonia is characterized by fever, bilateral infiltrates on chest radiograph, hypoxemia and alveolar eosinophilia. Chest auscultation may reveal bibasilar/diffuse crackles or transient wheezing. Interstitial infiltrates on chest imaging usually progress to extensive alveolar and interstitial infiltrates. Leukocytosis with neutrophilia or eosinophilia is common. Cladribine, fludarabine and interferon-alpha can rarely cause eosinophilic pneumonia. Eosinophilic pneumonia is steroid responsive (68-71).

\section{Granulomatous pneumonitis}

Granulomatous pneumonitis is seen in hypersensitivity-like pneumonitis and sarcoidosis. Loose non-necrotizing granulomas are described in hypersensitivity-like pneumonitis induced by fludarabine, rituximab and trofosfamide (22,24,26,34,37-41). Sarcoid-like disease is an uncommon complication of interferon therapy. Mediastinal lymphadenopathy, pulmonary infiltrate and noncaseating granulomas similar to sarcoidosis may develop after interferon therapy. Interferon-induced sarcoidosis tends to resolve after cessation of interferon therapy (72-75).

\section{NCPE and ARDS}

NCPE is a nonspecific term that is used to describe pulmonary edema not associated with heart failure. NCPE is caused by fluid retention and increased capillary leak caused by cytokine
TABLE 2

Agents associated with infiltrative lung diseases

Organizing pneumonia
Anthracyclines
Cladribine
Interferon-alpha
Rituximab
Thalidomide
Desquamative interstitial pneumonia
Cladribine
Interferon-alpha
Rituximab
Eosinophilic pneumonia
Cladribine
Fludarabine
Interferon-alpha
Granulomatous pneumonitis
Fludarabine
Interferon-alpha
Rituximab
Trofosfamide
Noncardiogenic pulmonary edema/acute respiratory distress syndrome
All-trans retinoic acid
Alemtuzumab
Arsenic trioxide
Cladribine
Cyclosporine
Dasatinib
Decitabine
Gemtuzumab
Imatinib
Interferonic trioxide
Pentostatin
Gemturinans retinamab

release. Pathology shows dilated lymphatic channels, alveolar septal edema, peribronchial edema, pleural effusion, pericardial effusion and occasionally ascites. Hydration with 5\% dextrose that is commonly performed before and after administration of some antineoplastic agents (eg, pentostatin) may contribute to formation of pulmonary edema. Pentostatin is a potent adenosine deaminase inhibitor used in the treatment of hairy cell leukemia. Fatal pulmonary edema and respiratory distress have been observed after pentostatin therapy especially in combination with fludarabine, carmustatin, etoposide, rituximab and high-dose cyclophosphamide (76-80). Decitabine is a new demethylating agent indicated in the management of patients with myelodysplastic syndrome. In a phase III trial (81), an increased incidence of pulmonary edema was reported ( $6 \%$ versus $0 \%$ in the placebo group). Imatinib results in fluid retention and pulmonary edema. Imatinib inhibits platelet-derived growth factor, which regulates fluid absorption in the intestines (51). Dasatinib is associated with pulmonary edema in approximately $4 \%$ of treated patients. Fluid retention may also lead to pleural 
effusion, pericardial effusion and ascites (47). The role of steroids in the management of NCPE is unknown. Supportive care and diuresis are the main therapeutic strategies.

ARDS as a severe type of NCPE has also been described as a potential complication of antineoplastic agents. Two types can be distinguished: lung injury and severe interstitial pneumonitis, and respiratory failure as a manifestation of infusionrelated reactions. Cyclosporine (82), all-trans retinoic acid (ATRA) (83), arsenic trioxide (84) and bortezomib (10) are associated with lung injury and diffuse alveolar damage that may present clinically as ARDS. Cyclosporine is used in the treatment of T-cell large granular lymphocyte leukemia. A high concentration of cyclosporine in pulmonary circulation after administration through a central line has been associated with development of lung injury and ARDS (82,85-87). Severe pneumonitis resulting in ARDS can be seen with anagrelide (9), azacytidine (17), cladribine (21), interferon-alpha (18), procarbazine (33), rituximab (37) and tositumomab $(19,20)$. Infusion-related reactions occur during or shortly after infusion of some antineoplastic agents (eg, monoclonal antibodies, anthracyclines). Clinical manifestations include fever, cough, dyspnea, wheezing, skin rash, vomiting and hypotension. Alemtuzumab and gemtuzumab ozogamicin infusionrelated reactions may also by complicated by pulmonary infiltrates and ARDS (88-90). Alemtuzumab is an anti-CD52 monoclonal antibody and is indicated in the treatment of chronic lymphocytic leukemia. Gemtuzumab ozogamicin is an anti-CD33 monoclonal antibody conjugated to a modified antitumour antibiotic, calicheamicin. This agent is active against CD33-positive acute myelogenous leukemia. Infusionrelated reactions due to cytokine release are common $(33 \%)$. Severe cases of ARDS have been described within a day of the gemtuzumab ozogamicin $2 \mathrm{~h}$ infusion. Leukocyte counts above $60 \times 10^{9} / \mathrm{L}$ has been observed in these patients. Reduction of peripheral blasts to below $30 \times 10^{9} / \mathrm{L}$ with hydroxyurea or leukopheresis before gemtuzumab ozogamicin infusion may prevent this potentially fatal pulmonary complication $(91,92)$.

\section{DAH}

DAH is characterized by hemorrhagic BAL return and presence of hemosiderin-laden macrophages in BAL. The clinical presentations are nonspecific and include fever, dyspnea and hemoptysis. ATRA, gemtuzumab and rituximab rarely induce DAH. High-dose steroids are used in the treatment of druginduced DAH (93-94).

\section{Retinoic acid syndrome}

ATRA and arsenic trioxide are effective therapies for acute promyelocytic leukemia (APL). Retinoic acid syndrome occurs two to 21 days after ATRA induction therapy in approximately $25 \%$ of patients. Fever, weight gain, generalized edema, respiratory distress, alveolar hemorrhage, renal failure, pericardial effusion, pleural effusions, cervical lymphadenopathy, intermittent hypotension, thromboembolism and intracranial hemorrhage are common clinical manifestations. A syndrome identical to retinoic acid syndrome occurs in approximately $30 \%$ of APL patients treated with arsenic trioxide. Retinoic acid syndrome occurs only during induction therapy. Retinoic acid syndrome has not been observed in postremission arsenic trioxide or ATRA therapies. Mortality for ATRA- and arsenic trioxide-induced retinoic acid syndrome are $4.5 \%$ and $1.4 \%$, respectively (95-104).
Chest imaging shows diffuse infiltrates, peripheral small nodules, consolidations or pulmonary edema. Pulmonary pathological findings include alveolar hemorrhage, pulmonary capillaritis, intra-alveolar myeloid cell infiltration, alveolar septal edema, diffuse alveolar damage and fibrinous exudates. ATRA and arsenic trioxide induce differentiation of APL cells to more mature cells in vitro and in vivo. This differentiation is thought to contribute to leukocytosis seen after initiation of the therapy. High peripheral leukocyte count was suggested as a possible risk factor for development of retinoic acid syndrome. This pharmacological cell differentiation may induce production and release of granulocyte-macrophage colony stimulating factor and cytokines like interleukin-1, tumour necrosis factor-alpha, interleukin- 6 and interleukin-8. These cytokines have been suggested to contribute to pulmonary toxicity in retinoic acid syndrome. Prior corticosteroid therapy (eg, prednisone $30 \mathrm{mg}$ ) may reduce the risk for retinoic acid syndrome. Systemic corticosteroids such as dexamethasone are the mainstay of therapy (95-104).

\section{OTHER PULMONARY TOXICITIES}

Bronchospasm during or shortly after administration of alemtuzumab (88), anthracyclines (16), gemtuzumab (92), interferonalpha (29), L-asparaginase (105), nelarabine (76) and rituximab (106) can occur. Pleural effusion can also occur as a pulmonary complication of antineoplastic agents and has been reported with all-trans retinoic acid (95-104), clofarabine (17), dasatinib (47), imatinib (107), interferon-alpha (29) and nelarabine (76). Because granulocyte and granulocutemacrophage colony stimulating factors are used commonly in cancer patients on chemotherapy, granulocyte and granulocute-macrophage colony stimulating factors-induced lung toxicity should be considered as part of the differential diagnosis. Acute interstitial pneumonitis and NCPE have been associated with use of granulocyte and granulocute-macrophage colony stimulating factors mainly in patients with non-Hodgkin's lymphoma (108-110).

\section{REFERENCES}

1. Camus P, Kudoh S, Ebina M. Interstitial lung disease associated with drug therapy. Br J Cancer 2004;91(Suppl 2):S18-S23.

2. Arning M, Heer-Sonderhoff AH, Wehmeir A, Schneider W. Pulmonary toxicity during infusion of liposomal amphotericin B in two patients with acute leukemia. Eur Clin Microbiol Infect Dis 1995;14:41-3.

3. Roncoroni AJ, Corrado C, Besuschio S, et al. Bronchiolitis obliterans possibly associated with amphotericin B. J Infect Dis 1990;161:589.

4. Pusateri DW, Muder RR. Fever, pulmonary infiltrates, and pleural effusion following acyclovir therapy for herpes zoster opthtalmicus. Chest 1990;98:754-6.

5. Couderc LJ, Stelianides S, Frachon I, et al. Pulmonary toxicity of chemotherapy and G/GM-CSF: A report of five cases. Respir Med 1999;93:65-8.

6. Anagrelide Study Group. Anagrelide, a therapy for thrombocythemic states: Experience in 577 patients. Am J Med 1992;92:69-76.

7. Tirgan AM, Lubin A, Sherman BW. Anagrelide-associated pulmonary interstitial fibrosis. Blood 1992;80(Suppl 1):445a.

8. Spencer EM, Lawrence DS. 'Double hit' from streptococcal pneumonia and hypersensitivity pneumonitis associated with anagrelide. Clin Lab Haem 2006;28:63-5.

9. Raghavan M, Mazer MA, Brink DJ. Severe hypersensitivity pneumonitis associated with anagrelide. Ann Pharmacother 2003;37:1228-31. 
10. Chew E, Filshie R, Wei A. Development of fatal bortezomib induced acute lung injury despite concurrent therapy with highdose dexamethasone. Leuk Lymphoma 2007;48:212-3.

11. Gotoh A, Ohyashiki K, Oshimi K, et al. Lung injury associated with brotezomib therapy in relapsed/refractory multiple myeloma in Japan: A questionnaire-based report from the "lung injury by bortezomib" joint committee of the Japanese society of hematology and the Japanese society of clinical hematology. Int J Hematol 2006;84:406-12.

12. Miyakoshi S, Kami M, Yuji K, et al. Severe pulmonary complications in Japanese patients after bortezomib treatment for refractory multiple myeloma. Blood 2006;107:3492-4.

13. Tomlinson J, Tighe M, Johnson S, Stone R, Nicholson AG, Rule S Interstitial pneumonitis following mitozantrone, chlorambucil and prednisolone (MCP) chemotherapy. Clin Oncol 1999;11:184-6.

14. Quigley M, Brada M, Heron C, et al. Severe lung toxicity with a weekly low dose chemotherapy regimen in patients with nonHodgkin's lymphoma. Hemotol Oncol 1988;6:319-24.

15. Matsukawa Y, Takeuchi J, Aiso M, et al. Interstitial pneumonitis possibly due to mitoxantrone. Acta Haematol 1993;90:155-8.

16. Skubitz KM, Skubitz APN. Mechanism of transient dyspnea induced by pegylated-liposomal doxorubicin (Doxil(TM)). Anti Cancer Drugs 1998;9:45-50.

17. Vidaza ${ }^{\text {TM }}$. <www.fda.gov/cder/foi/label/2004/050794lbl.pdf> (Version current at May 13, 2008).

18. Abi-Nassif S, Mark EJ, Fogel RB, et al. Pegylated interferon and ribavirin-induced interstitial pneumonitis with ARDS. Chest 2003;124:406-10.

19. Press OW, Eary JF, Appelbaum FR, et al. Radiolabeled-antibody therapy of B-cell lymphoma with autologous bone marrow support. N Engl J Med 1993;329:1219-24.

20. Press OW, Eary JF, Appelbaum FR, et al. Phase II trail of 131I-B1 (anti-CD20) antibody therapy with autologous stem cell transplantation for relapsed B- cell lymphomas. Lancet 1995;346:336-40.

21. Feenstra JFE, Hichey BP, Blackwell EA. Acute respiratory failure associated with cladribine pneumonitis. Inten Med J 2004;34:583-4.

22. Helman DL, Byrd JC, Ales NC, et al. Fludarabine-related pulmonary toxicity: A distinct clinical entity in chronic lymphoproliferative syndromes. Chest 2002;122:785-90.

23. Solal-Céligny P, Brice P, Brousse N, et al. Phase II trial of fludarabine monophosphate as first-line treatment in patients with advanced follicular lymphoma: A multicenter study by the Group d'Etude des Lymphomes de l'Adulte. J Clin Oncol 1996;14:514-9.

24. Hurst PG, Habib MP, Garewal H, et al. Pulmonary toxicity associated with fludarabine monophosphate. Invest New Drugs 1987;5:207-10.

25. Garg S, Grag MS, Basmaji N. Multiple pulmonary nodules: An unusual presentation of fludarabine pulmonary toxicity: Case report and review of literature. Am J Hematol 2002;70:241-5.

26. Levin M, Aziz M, Opitz L. Steroid-responsive interstitial pneumonitis after fludarabine therapy. Chest 1997;111:1472-3.

27. Raanani P, Ben-Bassat I. Immune-mediated complications during interferon therapy in hematological patients. Acta Haematol 2002;107:133-44

28. Wandl UB, Kloke O, Nagel-Hiemke M, et al. Combination therapy with interferon alpha-2b plus low dose interferon gamma in pretreated patients with $\mathrm{Ph}$-positive chronic myelogenous leukemia. Br J Haematol 1992;81:516-9.

29. Anderson P, Höglund M, Rödjer S. Pulmonary side effects of interferon- $\alpha$ therapy in patients with hematological malignancies. Am J Hematol 2003;73:54-8.

30. Mahmood T, Mudad R. Pulmonary toxicity secondary to procarbazine. Am J Oncol 2002;25:188-7.

31. Cersosimo RJ, Licciardello JT, Mathews SJ, et al. Acute pneumonitis associated with MOPP chemotherapy of Hodgkin's disease drug Intell Clin Pharm 1984;18:609-11.

32. Millward MJ, Cohney SJ, Byrne MJ, et al. Pulmonary toxicity following MOPP chemotherapy. Aust N Z J Med 1990;20:245-8.

33. Brooks BJ Jr, Hendler NB, Alvarez S, et al. Delayed life-threatening pneumonitis secondary to procarbazine. Am J Clin Oncol 1990;13:244-6

34. Kopp H-G, Kanz L, Hartmann JT. Hypersensitivity pneumonitis associated with the use of trofosfamide. Anti-Cancer Drugs 2004;15:603-4
35. Byrd JC, Murphy T, Howard RS, et al. Rituximab using a thrice weekly dosing schedule in B-cell chronic lymphocytic leukemia and small lymphocytic lymphoma demonstrates clinical activity and acceptable toxicity. J Clin Oncol 2001;19:2153-64.

36. Leon RJ, Fla Z. Rituximab-induced acute pulmonary fibrosis. Mayo Clin Proc 2004; 79:949-50.

37. Ghesquieres H. Severe interstitial pneumonitis following rituximab and bleomycin-containing combination chemotherapy. Ann Oncol 2005;16:1399-404.

38. Swords R, Power D, Fay M, et al. Interstitial pneumonitis following rituximab therapy for immune thrombocytopenic purpura (ITP). Am J Hematol 2004;77:103-4

39. Burton C, Kaczmarski R, Jan-Mohamed R. Interstitial pneumonitis related to rituximab therapy. N Engl J Med 2003;348:2690-1.

40. Herishanu Y, Polliack A, Leider-Trejo L, et al. Fatal interstitial pneumonitis related to rituximab-containing regimen. Clin Lymphoma Myeloma 2006;6:407-9.

41. Lee Y, Kyung SY, Choi SJ, et al. Two cases of interstitial pneumonitis caused by rituximab therapy. Korean J Intern Med 2006;21:183-6.

42. Rajkumar SV, Hayman S, Gertz MA, et al. Combination therapy with thalidomide plus dexamethasone for newly diagnosed myeloma. J Clin Oncol 2002;20:4319-23.

43. Iguchi T, Sakoda M, Chen CK, et al. Interstitial pneumonia during treatment with thalidomide in a patient with multiple myeloma. Rinsho Ketsueki 2004;45:1064-6.

44. Onozawa M, Hashino S, Sogabe S, et al. Side effects and good effects from new chemotherapeutic agents. Case 2. Thalidomideinduced interstitial pneumonitis. J Clin Oncol 2005;23:2425-6.

45. Rajkumar SV, Hayman SR, Lacy MQ, et al. Combination therapy with lenalidomide plus dexamethasone (Rev/Dex) for newly diagnosed myeloma. Blood 2005;106:4050-3.

46. Thornburg A, Abonour R, Smith P, et al. Hypersensitivity pneumonitis-like syndrome associated with use of lenalidome. Chest 2007;131:1572-4.

47. Bristol-Myers Squibb. <www.bms.com> (Version current March 5, 2007).

48. Kantarjian H, Pasquini R, Hamerschlak N, et al. Dasatinib or highdose imatinib for chronic-phase chronic myeloid leukemia after failure of first-line imatinib: A randomized phase 2 trial. Blood 2007;109:5143-50.

49. Talpaz M, Shah NP, Kantarjin H, et al. Dasatinib in imatinibresistant Philadelphia chromosome-positive leukemias. N Engl J Med 2006;354:2531-41

50. Radaelli F, Bramanti S, Fantini NN, et al. Dasatinib-related alveolar pneumonia responsive to corticosteroids. Leuk Lymphoma 2006;47:1180-1.

51. Ohnishi K, Sakai F, Kudoh S, et al. Twenty-seven cases of druginduced interstitial lung disease associated with imatinib. Leukemia 2006;20:1162-4.

52. Lin JT, Yeh KT, Fang HY, et al. Fulminant, but reversible interstitial pneumonitis associated with imatinib mesylate. Leuk Lymphoma 2006;47:1693-5.

53. Rajda J, Phatak PD. Reversible drug-induced interstitial pneumonitis following imatinib mesylate therapy. Am J Hematol 2005;79:80-1.

54. Grimison P, Goldstein D, Schneeweiss J, et al. Corticosteroidresponsive interstitial pneumonitis related to imatinib mesylate with successful re-challenge, and potential causative mechanisms. Intern Med J 2005;35:136-7.

55. Isshiki I, Yamaguchi K, Okamoto S. Interstitial pneumonitis during imatinib therapy. Br J Haematol 2004;125:420.

56. Ma CX, Hobday TJ, Jett JR. Imatinib mesylate-induced interstitial pneumonitis. Mayo Clin Proc 2003;78:1578-9.

57. Bergeron A, Bergot E, Vilela G, et al. Hypersensitivity pneumonitis related to imatinib mesylate. J Clin Oncol 2002;20:4271-2.

58. Muller N L, White D A, Jiang H, et al. Diagnosis and management of drug-associated interstitial lung disease. Br J Cancer 2004;91(Suppl 2):S24-S30.

59. Tsao YT, Dai MS, Chang H, et al. Bronchiolitis obliterans organizing pneumonia presenting as hemoptysis in a patient of Hodgkin's lymphoma undergoing chemotherapy. J Med Sci 2006;26:115-8.

60. Jacobs C, Slade M, Lavery B. Doxorubicin and BOOP. A possible near fatal association. Clin Oncol 2002;14:262.

61. Ogata K, Koga T, Yagawa K. Interferon- related bronchiolitis obliterans organizing pneumonia. Chest 1994;106:612-3. 
62. Mian M, Rass C, Hutarew G, et al. Extensive organizing pneumonia during chemo-immunotherapy containing rituximab and G-CSF in a patient with diffuse large B-cell lymphoma: Case report and review of the literature. Leuk Lymphoma 2006;47:1683-5.

63. Macartney C, Burke E, Elborn S, et al. Bronchiolitis obliterans organizing pneumonia in a patient with non-Hodgkin's lymphoma following R-CHOP and pegylated filgrastim. Leuk Lymphoma 2005;46:1523-6.

64. Biehn SE, Kirk D, Rivera MP, et al. Bronchiolitis obliterans with organizing pneumonia after rituximab therapy for non-Hodgkin's lymphoma. Hematol Oncol 2006;24:234-7.

65. Kalambokis G, Stefanou D, Arkoumani E, et al. Fulminant bronchiolitis obliterans organizing pneumonia following $2 \mathrm{~d}$ of treatment with hydroxyurea, interferon- $\alpha$ and oral cytarabine ocfosfate for chronic myelogenous leukemia. Eur J Haematol 2004;73:67-70.

66. Feaver AA, McCune DE, Mysliwiec AG, et al. Thalidomideinduced organizing pneumonia. South Med J 2006;99:1292-4.

67. The Drug-Induced Lung Diseases. <www.pneumotox.com>. (Version current at May 13, 2008).

68. Robak T, Blasins-Kamorawiec M, Krykowski E, et al. 2-chlorodeoxyadenosine (cladribine)-related eosinophilia in patients with lymphoproliferative diseases. Eur J Haematol 1997;59:216-20.

69. Sezer O, Scmid P, Hallek M, et al. Eosinophilia during fludarabine treatment of chronic lymphocytic leukemia. Ann Hematol 1999;78:475-7.

70. Trojan A, Meier R, Licht A, et al. Eosinophilic pneumonia after administration of fludarabine for the treatment of non-Hodgkin's lymphoma. Ann Hematol 2002;81:535-7.

71. Hoffman SD, Hammadeh R, Shah N. Eosinophilic pneumonitis secondary to pegylated interferon alpha-2b and/or ribavirin. Am J Gastroenterol 2003;98:S152.

72. Kikawada M, Ichinose Y, Kunisawa A, et al. Sarcoidosis induced by interferon therapy for chronic myelogenous leukemia. Respirology 1998;3:41-4.

73. Pietropaoli A, Modrak J, Utell M. Interferon- $\alpha$ therapy associated with the development of sarcoidosis. Chest 1999;116:569-72.

74. Fiorani C, Sacchi S, Bonacorsi G, et al. Systemic sarcoidosis associated with interferon- $\alpha$ treatment for chronic myelogenous leukemia. Haematologica 2000;85:1006-7.

75. Franková H, Gaja A, Hejlová N. Pulmonary sarcoidosis in a patient with essential thrombocythemia treated with interferon $\alpha$ : A short case report. Med Sci Monit 2000;6:380-2.

76. Nipent. <www.fda.gov/cder/warn/2005/Nipent_warn_ltr.pdf> (Version current at May 13, 2008).

77. Kahn RC, Carlon GC, Miller L, et al. Acute respiratory failure due to 2’Deoxycoformycin. Intensive Care Med 1982;8:101-1-4.

78. Corazzelli G, Capobianco G, Russo F, Frigeri F, Aldinucci D, Pinto A. Pentostatin (2'-deoxycoformycin) for the treatment of hepatosplenic gammadelta T-cell lymphomas. Haematologica 2005;90:ECR14.

79. Drapkin R, Di Bella NJ, Faragher DC, et al. Results of a phase II multicenter trial of pentostatin and rituximab in patients with low grade B-cell non-Hodgkin's lymphoma: an effective and minimally toxic regimen. Clin Lymphoma 2003;4:169-75.

80. Koller CA, Mitchell BS. Alterations in erythrocyte adenosine nucleotide pools resulting from 2'-deoxycoformycin therapy. Cancer Res 1983;43:1409-14.

81. Dacogen (decitabine) for injection. <www.mgipharma.com/ pdfs/dacogen_pi.pdf $>$ (Version current at May 13, 2008).

82. Li G-S, Ye Q-F, Xia S-S, et al. Acute respiratory distress syndrome after liver transplantation: Etiology, prevention and management. HBPD Int 2002;1:330-4

83. Gruson D, Hilbert G, Boiron JM, et al. Acute respiratory distress syndrome due to all-trans retinoic acid. Intensive Care Med $1998 ; 24: 642$

84. Hassaballa HA, Lateef OB, Silver MR, et al. Acute lung injury induced by arsenic trioxide in a patient with refractory myelodysplastic syndrome. J Crit Care 2005;20:111-3.

85. Walsh RF, Springate JE, Spivack BS, et al. Cyclosporine and adult respiratory distress syndrome. Transplantation 1988;46:776-7.

86. Bronsther O, Steiner R, Ward D, Gamboa E, Halasz N. Adult respiratory distress syndrome following intravenous cyclosporine. Clin Transpl 1986;128-34.
87. Powell-Jackson PR, Carmichael FJ, Calne RY, Williams R. Adult respiratory distress syndrome and convulsions associated with administration of cyclosporine in liver transplant recipients. Transplantation 1984;38:341-3.

88. Wendtner CM, Ritgen M, Schweighofer CD, et al. Consolidation with alemtuzumab in patients with chronic lymphocytic leukemia (CLL) in first remission - experience on safety and efficacy within a randomized multicenter phase III trial of German CLL Study Group (GCLLSG). Leukemia 2004;18:1093-101.

89. Enblad G, Hagberg H, Erlanson M, et al. A pilot study of alemtuzumab (anti-CD52 monoclonal antibody) therapy for patients with relapsed of chemotherapy-refractory peripheral T-cell lymphomas. Blood 2004;103:2920-4.

90. Nosari A, Morra E. Infectious toxicity using alemtuzumab. Haematologica 2004;89:1415-8.

91. Bross PF, Beitz J, Chen G, et al. Approval summary: Gemtuzumab ozogamicin in relapsed acute myeloid leukemia. Clin Cancer Res 2001;7:1490-6.

92. Leopold LH, Berger MS, Feingold J. Acute and long-term toxicities associated with gemtuzumab ozogamicin (Mylotarg) therapy of acute myeloid leukemia. Clin Lymphoma 2002;2(Suppl 1):S29-S34

93. Lin TS, Penza SL, Avalos BR, et al. Diffuse alveolar hemorrhage following gemtuzumab ozogamicin. Bone Marrow Transpl 2005;35:823-4.

94. Alexandrescu DT, Dutcher JP, O’Boyle K, et al. Fatal intra-alveolar hemorrhage after rituximab in a patient with non-Hodgkin lymphoma. Leuk Lymphoma 2004;45:2321-5.

95. Nicolls MR, Terada LS, Tuder RM, et al. Diffuse alveolar hemorrhage with underlying pulmonary capillaritis in the retinoic acid syndrome. Am J Respir Crit Care Med 1998;158:1302-5.

96. Tallman MS, Andersen JW, Schiffer CA, et al. Clinical description of 44 patients with acute promyelocytic leukemia who developed the retinoic acid syndrome. Blood 2000;95:90-5.

97. Tallman MS. Retinoic acid syndrome: A problem of the past? Leukemia 2002;16:160-1.

98. Jung JI, Choi JE, Hahn ST, Min CK, Kim CC, Park SH. Radiologic features of the all-trans-retinoic acid syndrome. AJR Am J Roentgenol 2002;178:475-80.

99. Amano Y, Tajika K, Mizuki T, et al. All-trans retinoic acid syndrome: Chest CT assessment. Eur Radiol 2001;11:1516-7.

100. Davis BA, Cervi P, Amin Z, et al. Retinoic acid syndrome: Pulmonary computed tomography (CT) findings. Leuk Lymphoma 1996;23:113-7.

101. Ofran Y, Avivi I, Gesundheit B, et al. Differentiation syndrome with lethal lung injury after arsenic trioxide treatment for myelodysplastic syndrome. Am J Hematol 2007;82:332-3.

102. Che-Pin Lin, Huang MJ, Chang IY, et al. Retinoic acid syndrome induced by arsenic trioxide in treating recurrent all-trans retinoic acid resistant acute promyelocytic leukemia. Leuk Lymphoma 2000;38:195-8.

103. Leelasiri A, Numbenjapol T, Prayoowiwat W, et al. Successful treatment of retinoic acid syndrome with dexamethasone: A case report. J Med Assoc Thai 2005;88(Suppl 3):S302-10.

104. Cupitt JM. A case of steroids in acute lung injury associated with retinoic acid syndrome. Anaesth Intensive Care 2000;28:202-4.

105. Ho DH, Brown NS, Yen A, et al. Clinical pharmacology of polyethylene glycol-L-asparaginase. Drug Metabol Dispo 1986; $14: 349-52$.

106. Byrd JC, Waselenko JK, Maneatis TJ, et al. Rituximab therapy in hematologic malignancy patients with circulating blood tumor cells: Association with increased infusion-related side effects and rapid blood tumor clearance. J Clin Oncol 1999;17:791-5.

107. Goldsby R, Pulsipher M, Adams R, et al. Unexpected pleural effusions in 3 pediatric patients treated with STI-571. J Ped Hematol Oncol 2002;24:694-5.

108. Eisenbeis CF, Winn D, Poelman S, et al. A case of pulmonary toxicity associated with G-CSF and doxorubicin administration. Ann Hematol 2001;80:121-3.

109. Gertz MA, Lacy M Q, Bjornsson J, et al. Fatal pulmonary toxicity related to the administration of granulocyte colony-stimulating factor in amyloidosis: A report and review of growth factor-induced pulmonary toxicity. J Hematother Stem Cell Res 2000;9:635-43.

110. Couderc LJ, Stelianides S, Frachon I, et al. Pulmonary toxicity of chemotherapy and G/GM-CSF: A report of five cases. Respir Med 1999;93:65-8. 


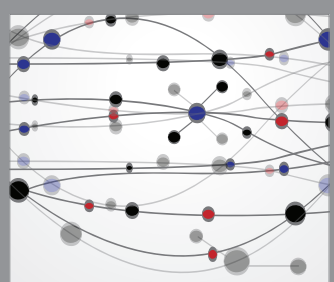

The Scientific World Journal
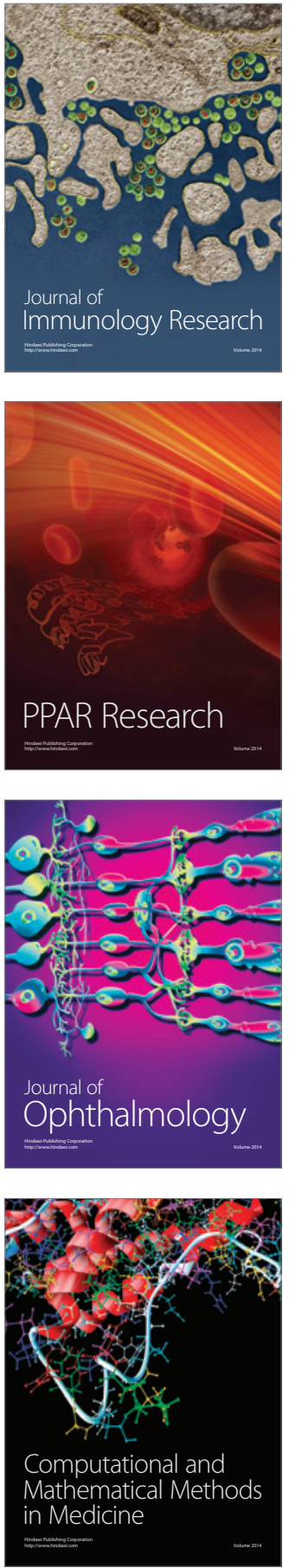

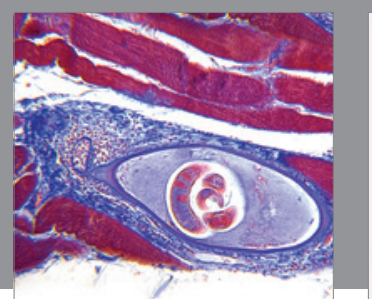

Gastroenterology Research and Practice

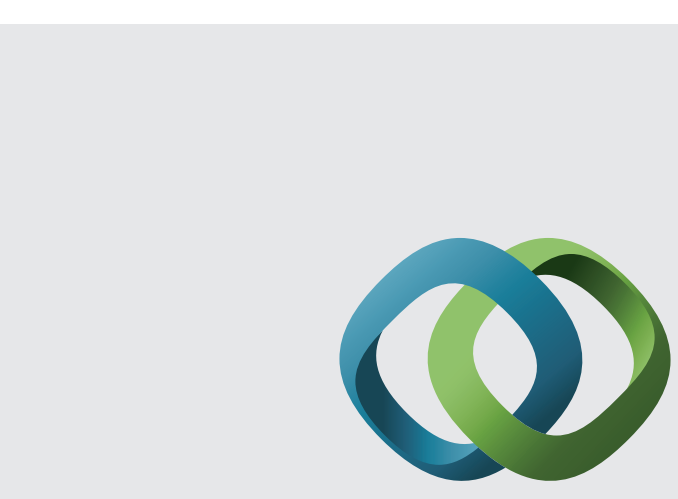

\section{Hindawi}

Submit your manuscripts at

http://www.hindawi.com
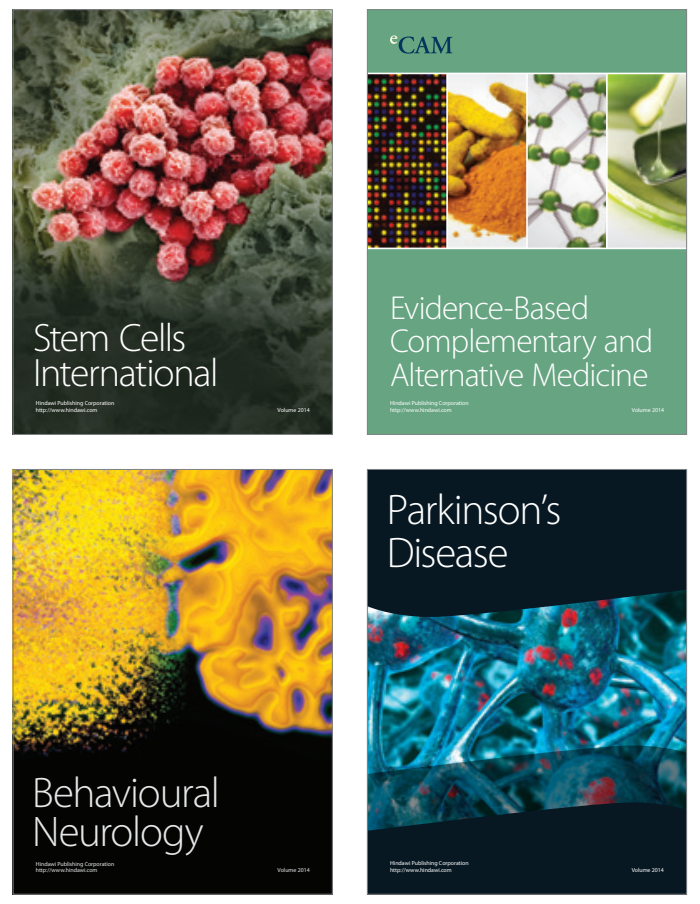
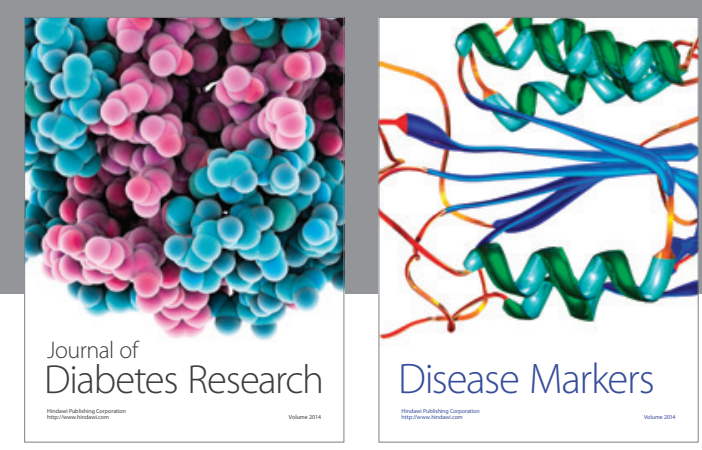

Disease Markers
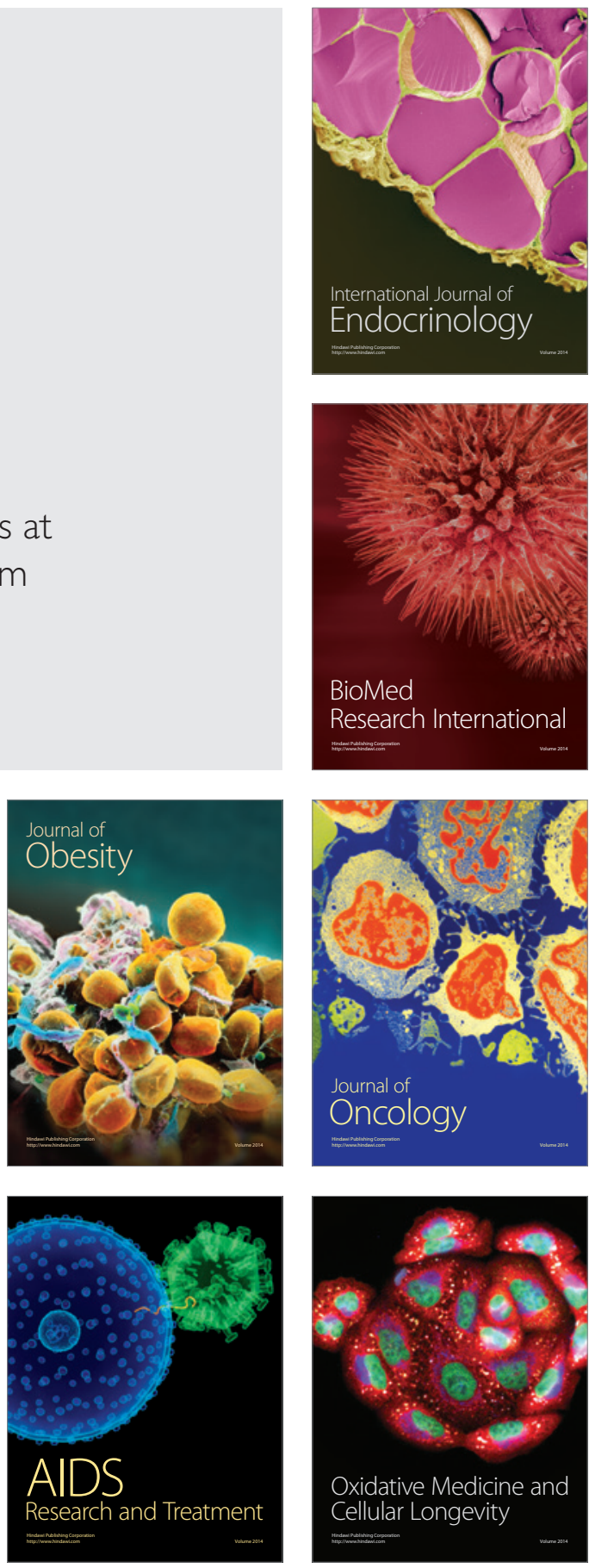